\title{
„Nic dobrego”? Kilka uwag o próbach prozatorskich Zdzisława Beksińskiego
}

„Wydaje mi się, że nigdy nie napiszę niczego dobrego”. Ta zanotowana w 1965 r. pod wpływem chwilowego zniechęcenia skarga dojrzałego - choć wciąż w kwiecie wieku - twórcy, wydaje się z dzisiejszej perspektywy przesadzona. Wydany pół wieku później wybór krótkiej prozy Zdzisława Beksińskiego [2015] dowodzi, że owo pełne żalu postanowienie było najwyżej w połowie słuszne: otóż artysta rzeczywiście nie próbował już swoich sił w literaturze (chociaż jego późniejsza nadpobudliwość epistolograficzna mogła być dowodem dalszego poszukiwania ujścia dla rozbudzonej pisarskiej pasji), natomiast to, co pozostawił w maszynopisach, z pewnością nie powinno być dlań powodem do wstydu.

Beksiński prozaikiem? Jego krótkotrwałe (1963-1965), aczkolwiek intensywne (ok. trzystu stron) doświadczenia z pisaniem nie

1 Uwaga autorska skreślona odręcznie na jednym z maszynopisów w 1965 r. Przytaczane w niniejszym tekście cytaty z odręcznych notatek Beksińskiego pochodzą ze zbiorów zdeponowanych w archiwum Muzeum Historycznego w Sanoku. Ponieważ oryginały często pozbawione są paginacji i nie zostały im nadane sygnatury, w niniejszym artykule po zacytowaniu nie podaje się numerów stron ineditów, z których pochodzą przytaczane fragmenty, a tylko skrótowiec „AMHs” zamknięty w nawiasie kwadratowym. 
powinny dziwić, jeśli wziąć pod uwagę zarówno różnorodność wcześniejszych i późniejszych pasji artystycznych (malarstwo, fotografia, rzeźba, rysunek, grafika tradycyjna i komputerowa, fotomontaże), jak i rozległe zainteresowania literackie. Co prawda artysta sam powściągliwie wypowiadał się w wywiadach o swoich inspiracjach (z obawy przed ,zaszufladkowaniem” zrezygnował nawet $\mathrm{z}$ tytułowania swoich plastycznych prac), nie jest jednak trudno ustalić listę przynajmniej paru ważnych dlań autorów [por. Banach 2011: 20; Grzebałkowska 2014: 79-80]. Pojawiają się tu między innymi: Edgar Allan Poe, Bruno Schulz, Franz Kafka, Samuel Beckett, Jorge Luis Borges, Witold Gombrowicz czy Alain Robbe-Grillet. Już te przykłady wyjaśniają w dużej części, jeśli nie wybór tematyki, to na pewno formalną stronę opowiadań mistrza z Sanoka.

Fascynacja poetyką oniryczną to jeden z najwyraźniejszych tropów interpretacyjnych, jakie możemy podjąć w trakcie lektury tej krótkiej prozy. Cytat z wiersza Poego Sen we śnie [Krzeczkowski, Sito, Żuławski, wybór i oprac. 1971: 456-457 $]^{2}$ powiesił artysta na ścianie swojej pracowni malarskiej jako motto. Powracająca na zakończenie każdej strofy utworu amerykańskiego klasyka fraza, a właściwie retoryczny zwrot: „Co widzimy, co wydaje się, / To jest tylko przyśnienie we śnie...” - to myśl, którą obsesyjnie powtarzają sobie narratorzy i protagoniści wielu tekstów Beksińskiego; myśl, którą w ślad za nimi podejmuje także czytelnik, niejednokrotnie zagubiony w meandrach wieloznacznego dyskursu.

Zagubienie odbiorcy bierze się z faktu, iż trudno mówić w przypadku opowiadań Beksińskiego o „akcji”, „intrydze” czy o „postaciach” albo „czasie”. Tradycyjne kategorie wzięte z podręcznika poetyki nie przystają do tych prozatorskich prób, które noszą już wszelkie znamiona nowoczesnej literatury drugiej połowy xx stulecia. Rzadko będziemy w stanie wyodrębnić tu jakąkolwiek historię: od pierwszego akapitu jesteśmy po prostu „wrzuceni”, jak bohater, w pewną sytuację, która wydaje się nie

2 Ta polska wersja tytułu wiersza Poego jest najpopularniejsza, ale we wskazanym tomie znajduje się przekład Józefa Czechowicza, który zaproponował tytuł $\mathrm{w}$ wersji wariantowej: Przyśnienie we śnie. 
mieć początku i zakończenia. Strzępy zdarzeń - zwykle w formie retrospekcji - pojawiają się wyjątkowo, jak na przykład w opowiadaniu Na końcu ogrodu: tekście utrzymanym w poetyce snu, a właściwie koszmaru, w którym pewne motywy wyraźnie nawiązują do Freudowskiej symboliki marzenia sennego (szuflada-tunel), inne z kolei swoimi akcesoriami bądź topografią delikatnie przypominają miniony koszmar Holokaustu (postaci Żydów, czarne sukna, park-cmentarzysko).

Większość opowiadań onirycznych Beksińskiego wymyka się wszelkim wyraźniejszym odniesieniom historycznym czy geograficznym, a zarazem typowemu epickiemu imperatywowi tworzenia zdarzeń i układania ich w ciągi logiczne. To raczej nieznośnie rozciągnięte w czasie hic et nunc, wieczne, ponadczasowe trwanie, sytuacja „w zawieszeniu”, bez możliwości rozwiązania. W tym literackim krajobrazie zredukowanym do monologu wewnętrznego trudno wręcz czasami ustalić - podobnie jak w powściągliwej prozie Becketta - kto opowiada, kim jest narrator. Wydaje się, że podczas lektury tekstów Nie ma już o czym opowiadać, Ręka, a także Lustra, Godzina zero czy Centrala snów czerpiemy wprost z czyjejś czystej jaźni, poza rzeczywistością i doznaniami zmysłowymi i oto spełnia się na tych kartach marzenie Aldousa Huxleya [2012], zapisane niegdyś w jednym z jego słynnych esejów, o otwarciu „drzwi percepcji”. Jednocześnie dziś, bogatsi o doświadczenia filmowe ostatnich lat, chętnie dopowiedzielibyśmy, że mentalna wędrówka narratora Beksińskiego po różnych poziomach świadomości, podświadomości i snów to przecież pomysły uderzająco podobne do tych znanych z klasyki kina ${ }^{3}$.

Niezwykle sugestywne w małych prozach Beksińskiego są obrazy przestrzeni urbanistycznej: pustych, złowrogich budynków o labiryntowej, iście borgesowskiej zabudowie, których iluzja trwania zostaje zwielokrotniona wszechobecnymi lustrami, zacierającymi granicę pomiędzy wnętrzem i zewnętrzem. Szczególnie przekonująco opisuje to autor w Placu egzekucji - panoramie wyludnionego miasta, w którym tytułowy plac to centralne

3 Por. chociażby takie tytuły, jak Matrix (The Matrix) [Wachowski, Wachowski, reż. 1999] czy Incepcja (Inception) [Nolan, reż. 2010]. 
miejsce, gdzie zbiegają się wszystkie ulice. Miasto zbudowane jest na idealnie wytyczonym planie ośmiokąta, z zachowaniem pełnej symetrii, choć tak naprawdę trudno to stwierdzić z całą pewnością, skoro granice tej postindustrialnej przestrzeni rozpływają się we mgle. Doświadczenie architektonicznego wykształcenia Beksińskiego łączy się tu z jego znajomością literatury antyutopijnej: jeśli już autor wypełnia swoje doskonale geometryczne przestrzenie miast ludźmi, są to tłumy oddające się podobnym czynnościom, zainteresowaniom i marzeniom (opowiadanie Bakterie) albo podporządkowane władcy absolutnemu (serie antymilitarnych utworów groteskowych: Alfa oraz Kronikarz wydarzeń).

Jeszcze inną, może nawet ważniejszą inspiracją dla tych budowanych symetrycznie i asymetrycznie planów była dla Beksińskiego tradycja nouveau roman. Zwłaszcza powieść Gumy Robbe-Grilleta wywarła na sanockim twórcy olbrzymie wrażenie i podsunęła mu, prócz geometrycznych pomysłów scenograficznych, niektóre rozwiązania formalne we własnym opowiadaniu Śnieg. Chodzi o próbę przedstawienia historii kryminalnej niejako „od tyłu” oraz zamazania tożsamości postaci tak skutecznie, że w końcu śledczy sam okazuje się zabójcą [Robbe-Grillet 1959]4․ Skojarzenie z „nową powieścią” francuską wydaje się uzasadnione także ze względu na związki tego gatunku z „Nową Falą” w kinie. W opowiadaniach Śnieg i Piasek artysta świadomie nawiązuje do estetyki dzieła kinematograficznego; oto narrator przyjmuje rolę i punkt widzenia operatora kamery, tworząc wystudiowane, czarno-białe „ujęcia”; raz będą to panoramy i travellingi, a innym razem - zbliżenia, detale, rekwizyty i elementy scenografii zewidzek (przełożoną na język polski dopiero w 1967 r.), był po jej lekturze zdruzgotany. Kilka lat później w liście do przyjaciela Andrzeja Urbanowicza, wciąż mając w pamięci swój zamknięty już epizod pisarski, zauważył niewiarygodne podobieństwo formalne między powieścią francuską i własnymi dawnymi wprawkami: „[...] poszczególne fragmenty można by wymieniać i chyba nikt by tego nie spostrzegł [...] lektura Domu schadzek wywoływała we mnie wybuchy obłędnego śmiechu, bo były tam fragmenty dosłownie takie same konstrukcyjnie" [Listy Beksińskiego do... 1996: 9]. Należy jednak pamiętać, że w tym przypadku sanocki artysta zupełnie bezwiednie doszedł do podobnych rezultatów twórczych. 
dencjonowane jak w filmowym scenopisie (echo niespełnionego marzenia Beksińskiego o studiowaniu reżyserii?). Oba przywołane powyżej tytuły zawierają dodatkowo autotematyczne komentarze odwołujące się do doświadczeń filmowych typowego kinomana: narrator co kilka akapitów dyskutuje z tradycją tzw. prawdy ekranowej i jej relacji z rzeczywistością.

Kino i intryga kryminalna to niejedyne nawiązania prozy Beksińskiego do popkultury. W niektórych tekstach autor umiejętnie wykorzystuje slogany reklamowe (amerykańskie, rzecz jasna, zważywszy na ówczesne realia Polski epoki Gomułki), zręcznie wplatając je w wypowiedzi lub w monologi wewnętrzne swoich postaci, albo też odwołuje się do poetyki komiksu, wyobrażając sobie pewne epizody jako narysowane historyjki z „dymkami” zawierającymi kwestie bohaterów. Ale są i takie tropy, które chętniej skojarzylibyśmy z kulturą wysoką. Kobieta z portretu stanowi erudycyjny traktat o technice malowania obrazu; Obserwatorzy demaskują iluzję sytuacji teatralnej, a niektóre wpisane tu kwestie żywo przypominają te znane z Publiczności zwymyślanej Handkego [1969] - tyle że... sztuka austriackiego pisarza powstała dopiero kilka lat później. Podobne zaskakujące antycypacje odnajdziemy w Zamachu - otwierająca opowiadanie scena do złudzenia przypomina sytuację z pierwszego rozdziału słynnej powieści Itala Calvina [1989] - czy w nierozwiniętym pomyśle na opisanie kolekcji fotografii „zawierających tego samego człowieka fotografowanego z tego samego miejsca codziennie, gdy wychodzi z domu, od czasów dzieciństwa do śmierci” [AMHs]; pomyśle, który dekadę później w Paryżu zrealizował w nieco innej formie Georges Perec $[1982]$ s.

Powyższe przykłady nie wyczerpują listy pomysłów tematycznych i formalnych Beksińskiego-prozaika. Opowiadania Podpalacz, Skrzyżowanie, Numer telefonu, Zamach należą co prawda do szeroko pojętej literatury sensacyjnej, ale w najróżniejszych jej odmianach, w dodatku zwykle mocno wypaczonych: od pseudo-

5 Książka ta, której tytuł - Tentative d'épuisement d'un lieu parisien - można przetłumaczyć jako „próbę wyczerpania pewnego miejsca paryskiego”, nie jest znana polskiemu czytelnikowi. 
powiastki detektywistycznej, poprzez thriller, kryminał aż po historię quasi-szpiegowską. W innych utworach mamy sceny surrealistyczne, których nie powstydziliby się klasycy sprzed stu lat, i makabreski typowe dla Henriego Michaux, Fernanda Arrabala czy Dina Buzattiego. To utwory mieszające humor z okrucieństwem (Ból głowy III), a w swym szaleństwie metodycznie punktujące wszystkie grzechy drobnomieszczańskiego światka (Bilardzista). Ba, jest nawet opowiadanie, jak twierdzi sam autor, niemal „pornograficzne” (Manekiny).

Jak już wspomniałem, niemal wszystkie owe teksty przynoszą destrukcję tradycyjnej narracji, postaci, czasu i miejsca. Z tego też powodu nastręczają problemów, także tych terminologicznych: nie są to bowiem opowiadania sensu stricto, a raczej, by powtórzyć za autorem, „okruchy, bezużyteczne szczątki, niedojedzone przez czas resztki” [Beksiński 2015: 31]. Stają się, jak chciał wówczas pewien argentyński pisarz, nie prozatorską „sumą”, a raczej „różnicą” [Cortázar 1998: 620]. „Okruchy” te, dodajmy, twórca chętnie - używając współczesnego języka - miksował i samplował, gdyż tworzenie wariantów czy raczej „wariacji na temat” leżało u podstaw jego metody twórczej - zwłaszcza w malarstwie, które ostatecznie przyniosło mu sławę.

Nie sądzę, by „szczątkowość” utworów literackich Beksińskiego mogła stanowić zarzut wobec autora. Nie mówimy przecież o zawodowym pisarzu, lecz o wszechstronnym artyście, który próbował swoich sił na różnych polach twórczej eksploracji i z różnym skutkiem. Często wątpił w swój talent („chyba nie potrafię niczego «naprawdę», tylko «wprowadzam się w trans»” [Listy Beksińskiego do przyjaciela 1996: 197]), z niektórych form definitywnie rezygnował; tak było $\mathrm{z}$ fotografią i właśnie $\mathrm{z}$ literaturą. A jednak, nawet jako ledwie zarysy opowiadań, nagie konstrukcje niewypełnione literackim tworzywem - wydają się te małe prozy interesujące $z$ dwóch przynajmniej powodów. Po pierwsze, tworzą cenne i zaskakujące uzupełnienie portretu Beksińskiego; po drugie zaś, czytane pół wieku później, stanowią znakomitą wędrówkę po XX-wiecznych modach literackich i technikach prozatorskich.

Czytelnikowi te opowiadania nie przyniosą poczucia zażenowania, a artyście - ujmy. Korzyść z ich wydania jest więc obopólna. 


\section{Bibliografia}

Banach Wiesław (2011), Foto Beksiński, Bosz, Olszanica.

Beksiński Zdzisław (2015), Opowiadania, wybór i opracowanie krytyczne Tomasz Chomiszczak, Bosz, Olszanica.

Calvino Italo (1989), Jeśli zimową noca podróżny, przeł. Anna Wasilewska, PIW, Warszawa.

Cortázar Julio (1998), Gra w klasy, przeł. Zofia Chądzyńska, MUZA SA, Warszawa.

Grzebałkowska Magdalena (2014), Beksińscy. Portret podwójny, Znak, Kraków.

Handke Peter (1969), Publiczność zwymyślana, przeł. Helmut Kajzar, „Dialog”, nr 6, s. 46-63.

Huxley Aldous (2012), Drzwi percepcji. Niebo i piekło, przeł. Marta Mikita, Cień Kształtu, Warszawa.

Krzeczkowski Henryk, Sito Jerzy S., Żuławski Juliusz, wybór i oprac. (1971), Poeci języka angielskiego, t. 2, PIW, Warszawa.

Listy Beksińskiego do przyjaciela (1996), [dostęp: 2 lutego 2016], http://beksinski.dmochowskigallery.net/library.php.

Nolan Christopher, reż. (2010), Incepcja (Inception), usA-Wielka Brytania, DVD, dystr. Galapagos.

Perec Georges (1982), Tentative d'épuisement d'un lieu parisien, Editions

Christian Bourgois, Paris.

Robbe-Grillet Alain (1959), Gumy, przeł. Leszek Kossobudzki, Czytelnik, Warszawa.

Wachowski Andrew, Wachowski Laurence, reż. (1999), Matrix [ang. The Matrix] USA, DvD, dystr. Warner Home Video.

Tomasz Chomiszczak

"Nothing good"? A few notes on prose attempts by Zdzisław Beksiński

The article concerns with still not well-known part of the artistic work of Zdzisław Beksiński (a famous photographer, painter and graphic designer). In the 1960 s the artist was occupied with literature as well. He wrote short prose which reflected many modern literary fashions and trends, and even anticipated some of them.

In his literary works Beksiński was especially influenced by the suggestive aesthetics of the onirism, geometric architecture, and anti-Utopian novels. Sometimes, his narration refers to modern pop culture: the technique of film or the convention of comic strips; what is more, he applies the style of commercials and propaganda slogans. The artist from Sanok 
also adored writing different variations of the same story which let him play with various genres and plots. But, whatever he did, it was all about the construction, the form. His literary texts record their narrator's consciousness in a minimalist way, without any traditional literary frills. Therefore Beksiński unconsciously realized the idea postulated at the same time by Cortázar: each prose work should not be a "sum", but rather a kind of "difference".

This prose substantially complements our knowledge of the whole art of Beksiński, a natural genius, and remains another alternative part of his creative activities.

Keywords: onirism; cinema; architecture; thriller; anti-Utopia; form.

Tomasz Chomiszczak - romanista, literaturoznawca, profesor nadzwyczajny w Zakładzie Kultury, Mediów i Języków Państwowej Wyższej Szkoły Zawodowej w Sanoku. Jego zainteresowania badawcze, oprócz współczesnego piśmiennictwa frankofońskiego, w tym także xx-wiecznego dramatu i teatru (m.in. tłumaczył na język polski nową dramaturgię francuskojęzyczną), dotyczą kultury pogranicza rozumianego zarówno jako kategoria kulturowa (obszary kresowe), jak i estetyczna (korespondencja sztuk, gatunki „nieczyste"). Ostatnio napisal monografię Mistrz ceremonii. Marian Pankowski - od filologii do rytuatu (2014), wybrał i przetłumaczył z francuskiego brukselskie artykuły naukowe Mariana Pankowskiego (2014), opracował IBL-owską antologię dramatów tego pisarza (2015) oraz Opowiadania Zdzisława Beksińskiego (2015). Redaktor naczelny pisma „Acta Pancoviana”. 